\title{
Studies on Pharmacognosical Characteristics and Phytochemical Analysis of Manilkara hexandra (Roxb.) Dubard
}

\author{
Ettiappan Munuswamy ${ }^{a,}{ }^{*}$, Sukumaran Surabi $^{a}$, Karmegam Nandhagopal $^{a}$, Murugesan Sivagamasundari $^{b}$, \\ Dhurairaj Satheesh ${ }^{d}$ \\ aPG Department of Plant Biology and Plant Biotechnology, Loganatha Narayanaswamy Government College (Autonomous), Ponneri - \\ 601 204. Thiruvallur District, Tamil Nadu. \\ bDepartment of Botany, Arignar Anna Arts College for Women, Walajapet - 632 513, Tamilnadu, India. \\ 'PG and Research Department of Chemistry, Loganatha Narayanasamy Government College, (Autonomous), Ponneri-601 204, \\ Tamilnadu, India. \\ *Corresponding author's E-mail: em.sam12@gmail.com
}

Received: 11-06-2021; Revised: 19-08-2021; Accepted: 26-08-2021; Published on: 15-09-2021.

\section{ABSTRACT}

Medicinal Plants have been playing a significant role in the treatment of various ailments in India. The important traditional methods in our country are Ayurvedic, Homeopathy, Unnai and Siddha systems of medicine. Manilkara hexandra plant bark was used in Febrifuge and the latex used in giddiness, aphrodisiac, general debility. This review attempts to encompass the available literature of Manilkara hexandra with respect to traditional uses, Pharmacognosical characteristics and phytochemical analysis.

Keywords: Phytochemistry, Pharmacological, Mimusops hexandra and Leaf Extract.

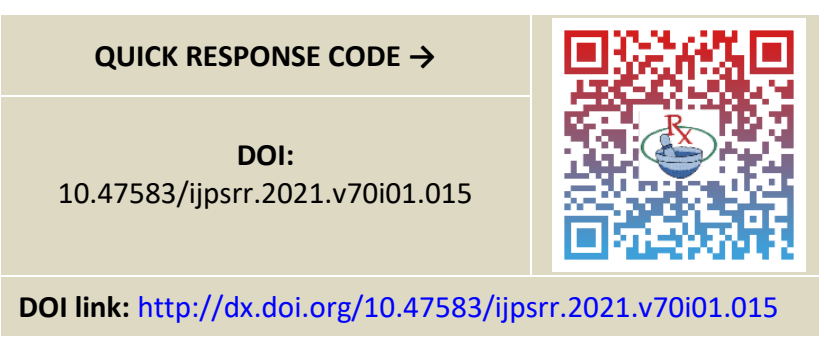

\section{INTRODUCTION}

$\mathrm{M}$ edicinal Plants have been playing a significant role in the treatment of various ailments in India. The important traditional methods in our country are Ayurvedic, Homeopathy, Unnai and Siddha systems of Medicine. The world health organization has emphasized the utilization of indigenous system of Medicines based on the locally available raw materials, i.e. Medicinal Plants. Furthermore, approximate one third of all drugs are plant based and if bacteria and fungi also included, nearly $60 \%$ of pharmaceuticals are of Plant origin. Our country is rich in large number of such plants that either be used directly or as the source of active principles in formulation of drugs curing dreaded diseases ${ }^{1}$.

India as a whole is the richest source of medicinal plants which are distributed in almost all parts of the country. The herb collectors and small traders collect the drugs for the manufactures of Ayurvedic and Unani medicines. But there is a shortage of these materials for maintaining the sustained supply to the plant based drug industries. It is also not proper under the present situation to be dependent only on natural resources to keep the wheel of the industries running all the time in view of the fast depleting natural wealth. This call for the domestication and Cultivation of these plants as well as increment of the drug production with uniformly high potency. At the same time increased demand of Plant raw materials has led to over exploitation of wild plants resulting into serious hazard. This necessitates the urgent need of their systematic cultivation for constant supply to the use industries.

Manilkara hexandra is an Evergreen, small trees; latex milky. Leaves clustered at the ends of branches, coriaceous, shining, broadly ovate or oblong, entire, emarginate, base obtuse or acute, glabrous, dark-green above, paler below, secondary nerves 20-26 pairs, parallel, impressed above, raised below. Flowers white, axillary, solitary or in clusters. Calyx lobes 6 , in 2 series of 3 each. Corolla lobes 18 , in 3 series of 6 each, valvate. Stamens 6 , alternate with the staminodes. Ovary 6-locular; ovule 1 or 2 per locules, axile. Berries ellipsoid, reddish-yellow when ripe; seed one, ovoid.

The plant bark was used in Febrifuge and the latex used in giddiness, aphrodisiac, general debility².

\section{MATERIALS AND METHODS}

Manilkara hexandra leaf was collected from Ponneri, Tamil Nadu, India in the form of dry sample.

Pharmacognostic Evaluations and Qualitative phytochemical analysis methods are followed from the published methods ${ }^{3}$. 


\section{RESULTS}

\section{Pharmacognosical characteristics}

The characteristics of Pharmacognosical significance of the leaves sample (shade dried and powdered leaves sample) have been studied as a part of the evaluation of their antimicrobial. Conventional parameters such as fluorescence characteristics, ash values, exhaustive extractive values and qualitative phytochemical characteristics of the leaves sample have been determined.

\section{Fluorescence characteristics}

Table 1 present the fluorescence characteristics of the leaves sample. The sample was green in colour, while their solvent extracts fluorescence differently in normal and UV lights. The shade dried, powdered sample of Manilkara hexandra exhibited distinct fluorescence characteristics as could be seen in the data provided in the Table 1.

Table 1: Fluorescence characteristics of Manilkara hexandra* in different solvents

\begin{tabular}{|c|c|c|c|}
\hline $\begin{array}{l}\text { S. } \\
\text { No. }\end{array}$ & Solvent & Day light & $\begin{array}{l}\text { UV light } \\
(254 \mathrm{~nm})\end{array}$ \\
\hline 1. & Hexane & Pale green & Green \\
\hline 2. & Benzene & Dark green & Green \\
\hline 3. & Chloroform & $\begin{array}{l}\text { Yellowish } \\
\text { Green }\end{array}$ & $\begin{array}{l}\text { Yellowish } \\
\text { green }\end{array}$ \\
\hline 4. & Ethyl acetate & Green & Dark Green \\
\hline 5. & $\begin{array}{l}\text { Petroleum } \\
\text { ether }\end{array}$ & Light Green & Green \\
\hline 6. & Acetone & $\begin{array}{l}\text { Yellowish } \\
\text { Green }\end{array}$ & Dark Green \\
\hline 7. & Ethanol & Pale Green & Green \\
\hline 8. & Water & Light Green & $\begin{array}{l}\text { Yellowish } \\
\text { green }\end{array}$ \\
\hline 9. & $\begin{array}{l}\text { Acid } \\
\left.\mathrm{H}_{2} \mathrm{SO}_{4}\right)\end{array}$ & $\begin{array}{l}\text { Greenish } \\
\text { Brown }\end{array}$ & $\begin{array}{l}\text { Greenish } \\
\text { Black }\end{array}$ \\
\hline 10. & Alcoholic $\mathrm{KOH}$ & Pale green & Green \\
\hline 11. & Aqueous $\mathrm{KOH}$ & $\begin{array}{l}\text { Pale } \\
\text { Yellowish } \\
\text { green }\end{array}$ & $\begin{array}{l}\text { Yellowish } \\
\text { Green }\end{array}$ \\
\hline 12. & Methanol & Green & Dark Green \\
\hline 13. & $\begin{array}{l}\text { Leaves powder } \\
\text { as such }\end{array}$ & Pale brown & Pale brown \\
\hline
\end{tabular}

*Shade dried powdered material

\section{Ash values and exhaustive extractive values}

Ash values and exhaustive values for Manilkara hexandra are given in Table 2. In the Manilkara hexandra, of total ash value was $45.76 \%)$. Water-soluble ash content was (25.42 \%). Exhaustive extractive values for the leaves sample given in Table 2.
Table 2: Ash values and exhaustive extractive values for the leaves sample

\begin{tabular}{|l|l|l|}
\hline $\begin{array}{l}\text { S. } \\
\text { No. }\end{array}$ & Parameters & $\begin{array}{l}\text { Manilkara } \\
\text { hexandra } \\
\text { (\%) }\end{array}$ \\
\hline 1. & Total Ash & 45.76 \\
\hline 2. & Water Soluble Ash & 25.42 \\
\hline 3. & $\begin{array}{l}\text { Alkalinity of water soluble ash (ml } \\
\text { 0.1N HCl Required to neutralize }\end{array}$ & $0.16 \mathrm{ml}$ \\
\hline 4. & Acid Insoluble Ash & 40.26 \\
\hline 5. & Alcohol soluble Extractive & 1.3 \\
\hline 6. & Water soluble Extractive & 0.22 \\
\hline 7. & $\begin{array}{l}\text { Exhaustive Extractive valve for } \mathrm{n}- \\
\text { Hexane }\end{array}$ & 1.86 \\
\hline 8. & Do for Chloroform & 2.55 \\
\hline 9. & Do for Methanol & 3.26 \\
\hline 10. & Petroleum ether & 5.75 \\
\hline 11. & $\begin{array}{l}\text { Do for Chloroform Methanol (2:1) } \\
\text { v/v }\end{array}$ & 3.7 \\
\hline
\end{tabular}

\section{Qualitative phytochemical Properties}

Qualitative phytochemical properties of leaves sample are given in Table 3. Tests for Alkaloids, triterpenes, Steroids, Tannin, Saponin, coumarins, flavonoids, quinones, Phenols, Proteins, Glycosides gum, fat, oils and furan derivatives were negative indicating their absence. Nevertheless, the sample tested positive for alkaloids, Triterpenes, Tannin, steroids, flavonoidss, phenols, proteins glycosides.

Table 3: Qualitative Phytochemistry of the leaves sample

\begin{tabular}{|l|l|l|}
\hline S. No. & Parameters & $\begin{array}{l}\text { Manilkara } \\
\text { hexandra }\end{array}$ \\
\hline 1. & Alkaloids & + \\
\hline 2. & Triterpenes & - \\
\hline 3. & Steroids & + \\
\hline 4. & Coumarin & - \\
\hline 5. & Tannin & - \\
\hline 6. & Saponin & + \\
\hline 7. & Flavonoids & - \\
\hline 8. & Quinones & + \\
\hline 9. & Phenols & - \\
\hline 10. & Gum & + \\
\hline 11. & Proteins & + \\
\hline 12. & Glycosides and Sugars & - \\
\hline 13. & Fats and Oils & \\
\hline 14. & Indole / furan & - \\
\hline (+) - Presence, (-)-Absence & \\
\hline
\end{tabular}




\section{DISCUSSION}

Qualitative phytochemical screening and quantified total phenolic and alkaloidal contents of plant leaves of Andrographis paniculata revealed the presence of steroids, triterpenoids, glycosides, flavonoids, Quinones, saponins, tannins, alkaloids, phenols, Proteins, carbohydrates and oil. The methanolic extract shows higher amount of alkaloid and the ethanolic extracts has more phenolic compound and antioxidant activity was found to be more in methanolic extract ${ }^{4}$.

Phytochemical analyses of Alangium salvifolium leaf gall was performed ${ }^{5}$. Result of phytochemical analysis of this extract revealed the presence of tannins, steroids, saponin, alkaloids, phenols, proteins, glycosides and sugars.

The observations made in the present study have clearly showed the bioactive potential of the plant Manilkara hexandra in medicine. The leaves sample exhibited fluorescence characteristics, ash values and exhaustive extractive values. Leaves sample exhibited qualitative phytochemical properties.

\section{REFERENCES}

1. Mohamed Ali. Text book of Pharmacognosy. 2nd Ed. 1994.

2. Madhava Chetty. K, Sivaji. K, Tulasi rao. K. Flowering plants of Chittoor district Andhra Pradesh, India. 2008.

3. Peach, K., Tracoy, M. V. Modern methods of plant analysis. Vol. I. Springer Verlag. Berlin. 1955.

4. Munuswamy. E., Nandhagopal. K. Studies on Pharmacognosical Characteristics and Phytochemical analysis of Andrographis paniculata (Burm.f) wall. ex Nees. International journal of Research and Analytical Review (IJRAR). 2018;5(4):380 - 383.

5. Munuswamy Ettiappan, Nandhagopal Karmegam. Studies on Pharmacognosical Characteristics and Phytochemical analysis of Alangium salvifolium (L.f) Wangerin leaf gall. Journal of information and Computational science. 2020;10(1):977-981.

Source of Support: The author(s) received no financial support for the research, authorship, and/or publication of this article.

Conflict of Interest: The author(s) declared no potential conflicts of interest with respect to the research, authorship, and/or publication of this article.

For any question relates to this article, please reach us at: editor@globalresearchonline.net New manuscripts for publication can be submitted at: submit@globalresearchonline.net and submit_ijpsrr@rediffmail.com 